\title{
Erratum to: Phytoplankton variability in relation to some environmental factors in the eastern coast of Suez Gulf, Egypt
}

\author{
Mohamed Z. Nassar • Nihal G. Shams El-Din • \\ Samiha M. Gharib
}

Published online: 25 January 2016

(C) Springer International Publishing Switzerland 2016

\section{Erratum to: Environ Monit Assess (October 2015) 187, Issue 10:4874 DOI 10.1007/s10661-015-4874-y}

The original version of this article contained mistakes.

The corrected abstract paragraph, Table 2 and Table 6 are shown below in bold.

Water samples were seasonally collected from 12 stations of the eastern coast of Suez Gulf during autumn of 2012 and winter, spring, and summer of 2013 in order to investigate phytoplankton community structure in relation to some physicochemical parameters. The study area harbored a diversified phytoplankton community (138 species), belonging to 67 genera. Four algal groups were represented and classified as Bacillariophyceae (90 species), Dinophyceae (28 species), Cyanophyceae (16

The online version of the original article can be found at http://dx. doi.org/10.1007/s10661-015-4874-y.

M. Z. Nassar $(\bowtie)$

National Institute of Oceanography and Fisheries, B.O.182, Suez, Egypt

e-mail: mnassar65@yahoo.com

N. G. S. El-Din - S. M. Gharib

National Institute of Oceanography and Fisheries, Alexandria, Egypt species), and Chlorophyceae (4 species). The results indicated a relative high occurrence of some species namely.; Pleurotaenium trabecula of green algae; Chaetoceros lorenzianus, Proboscia alata var. gracillima, Pseudosolenia calcar avis, and Pseudonitzschia pungens of diatoms; Trichodesmium erythraeum and Pseudoanabaena limnetica of cyanophytes. Most of other algal species were fairly distributed at the selected stations of the study area. The total abundance of phytoplankton was relatively low (average of 2989 unit/L) in the eastern coast of Suez Gulf, as compared its western coast and the northern part of the Red Sea. The diversity of phytoplankton species was relatively high (2.35-3.82 nats) with an annual average of 3.22 nats in the present study. The results concluded that most of eastern coast of Suez Gulf is still healthy, relatively unpolluted, and oligotrophic to mesotrophic area, which is characterized by the low values of dissolved phosphate $(0.025-0.3 \mu \mathrm{M})$, nitrate $(0.18-1.26 \mu \mathrm{M})$, and relatively high dissolved ammonium $(0.81-5.36 \mu \mathrm{M})$. Even if the occurrence of potentially harmful algae species was low, the study area should be monitored continuously. The dissolved oxygen ranged between 1.77 and $8.41 \mathrm{mg} / \mathrm{L}$ and $\mathrm{pH}$ values between 7.6 and 8.41. The multiple regression analysis showed that the dissolved nitrate and $\mathrm{pH}$ values were the most effective factors that controlled the seasonal fluctuations of phytoplankton along the eastern coast of Suez Gulf during 2012-2013. 
Table 2 Relative counts of the recorded phytoplankton species (unit/L) along the eastern coast of Suez Gulf during 2012-2013

\begin{tabular}{lllllllllllllllll}
\hline Algal groups & 1 & 2 & 3 & 4 & 5 & 6 & 7 & 8 & 9 & 10 & 11 & 12 \\
\hline
\end{tabular}

Diatoms

Amphiprora alata (Ehrenberg) Kützing (ab)

Amphiprora paludosa W. Smith (ab)

Amphora grevilleana Gregory (WoRMS)

Amphora lineolata Ehrenberg (ab)

Amphora marina W. Smith (ab)

Amphora ovalis (Kützing) Kützing (WoRMS)

Asterionella sp.

Asterolampra sp.

Aulacoseira granulata var angustissima (O.F. Müller)

Simonsen (ab)

Aulacoseira italica (Ehrenberg) Simonsen (ab)

Bacillaria paradoxa J.F. Gmelin (ab)

Campylodiscus hibernicus Ehrenberg (ab)

Chaetoceros coarctatus* Lauder (ab)

Chaetoceros curvisetus* Cleve (ab)

Chaetoceros densus* (Cleve) Cleve (ab)

Chaetoceros lorenzianus* Grunow (ab)

Chaetoceros peruvianus* Brightwell (ab)

Climacodium biconcavum Cleve (WoRMS)

Climacosphenia moniligera Ehr. (ab)

Cocconeis placentula Ehrenberg (ab)

Coscinodiscus centralis Ehrenberg (WoRMS)

Coscinodiscus granii Gough (ab)

Coscinodiscus marginatus Ehrenberg (ab)

Coscinodiscus radiatus Ehrenberg (WoRMS)

Cyclotella meneghiana* Kützing (ab)

Cymbella aspera Ehrenberg Cleve (WoRMS)

Cymbella sp.

Cymbella ventricosa (C.Agardh) C.Agardh (ab)

Diploneis interrupta (Kützing) Cleve (ab)

Diploneis sp.

Fragillaria pectinalis (O.F.Müller), Lyngbye (ab)

Fragillaria construens Ehrenberg Grunow (ab)

Fragillaria sp.

Gramatophora marina (Lyngbye) Kützing (ab)

Gramatophora oceanica Ehrenberg (WoRMS)

Guinardia flaccida (Castracane) H.Peragallo (ab)

Gyrosigma acuminatum (Kützing) Rabenhorst (WoRMS)

Gyrosigma attenuatum (Kützing) Rabenhorst (ab)

Gyrosigma balticum (Ehrenberg) Rabenhorst(WoRMS)

Hemiaulus membranaceus Cleve

Hemiaulus sinensis Greville

Lauderia annulata Cleve (WoRMS)

Leptocylindrus danicus $(\mathrm{ab})$

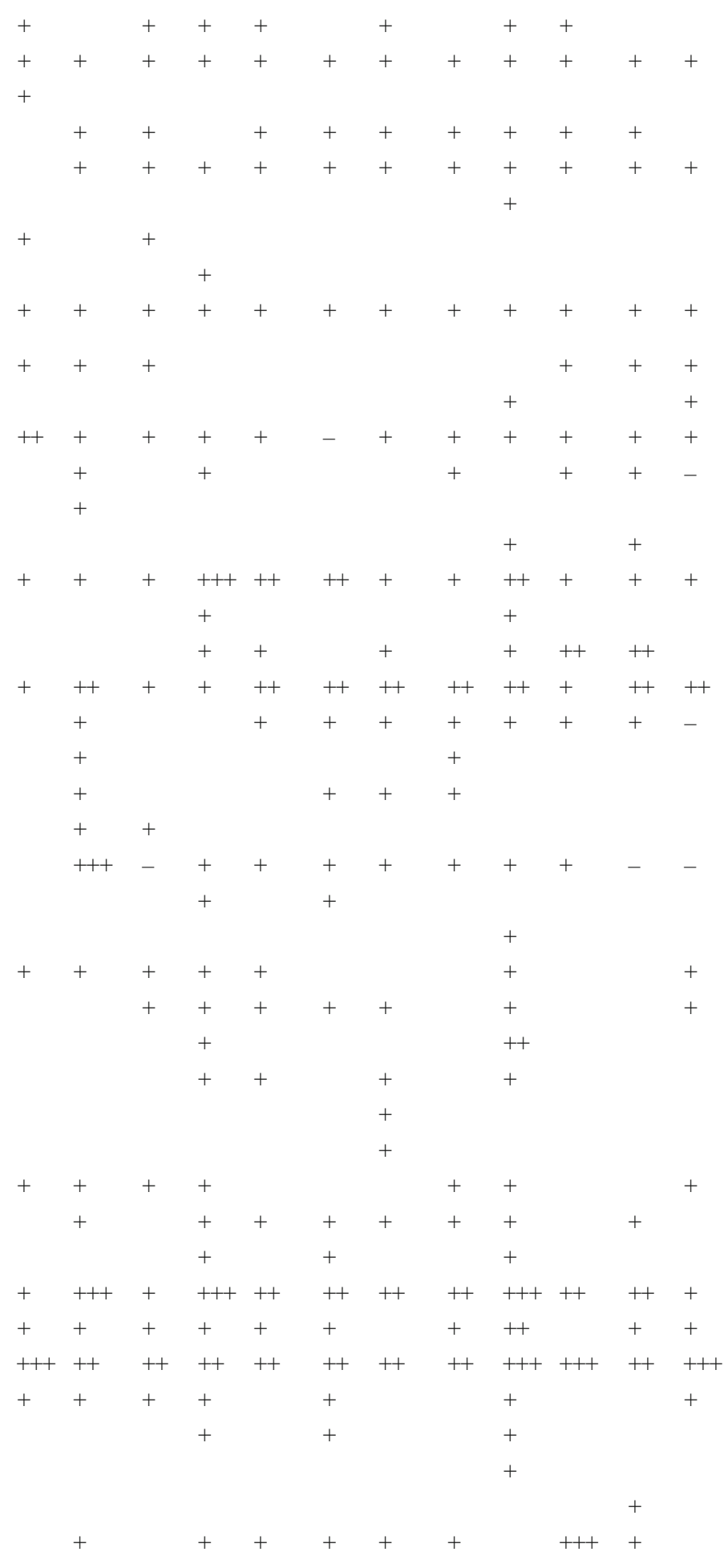


Table 2 (continued)

\begin{tabular}{|c|c|c|c|c|c|c|c|c|c|c|c|c|}
\hline Algal groups & 1 & 2 & 3 & 4 & 5 & 6 & 7 & 8 & 9 & 10 & 11 & 12 \\
\hline Leptocylindrus minimus Granv (WoRMS) & +++ & +++ & + & + & ++ & + & ++ & ++ & + & + & + & + \\
\hline Leptocylindrus sp. & + & & + & + & & & & & + & & & + \\
\hline Licmophora abbreviata C. Agardh (ab) & & & & + & & & & & + & & & \\
\hline Licmophora flabellata C. Agardh (ab) & + & + & ++ & ++ & + & ++ & + & ++ & ++ & ++ & + & ++ \\
\hline Licmophora gracilis (Ehrenberg) Grunow (WoRMS) & + & + & + & + & + & + & + & + & + & + & + & + \\
\hline Mastogloia sp. & & + & & & & & + & + & & & + & \\
\hline Melosira sp. & & & & + & & & & & & & & + \\
\hline Melosira varians C.Agardh (ab) & + & & & & & & & + & & + & + & \\
\hline Navicula dicephala (Ehrenberg) W. Smith (ab) & & & + & + & & & + & & + & & & + \\
\hline $\begin{array}{l}\text { Navicula tripunctata (O.F. Müller) Bory de Saint-Vincent } \\
\text { (WoRMS) }\end{array}$ & + & + & + & ++ & + & + & + & + & + & + & + & + \\
\hline Navicula placentula (Ehrenberg) Kützing (ab) & & & & + & + & + & + & & ++ & + & + & \\
\hline Navicula sp & & & + & + & & + & + & & + & & & + \\
\hline Nitzschia acicularis (Kütz.) W.Sm. & + & + & + & + & + & + & + & + & ++ & + & + & + \\
\hline Nitzschia closterium* (Ehrenberg) W.Smith (ab) & + & & + & + & & & & & + & & & + \\
\hline Nitzschia longissima* Brébisson) Ralfs in Pritchard (ab) & ++ & + & + & + & ++ & + & + & ++ & ++ & ++ & +++ & + \\
\hline Nitzschia obtusa W. Smith (ab) & + & + & + & + & + & + & + & + & + & + & + & + \\
\hline $\begin{array}{l}\text { Nitzschia pungens* var. atlantica (Grunow ex Cleve) } \\
\text { G.R.Hasle, }(\mathrm{ab})\end{array}$ & + & + & + & +++ & ++ & ++ & + & ++ & +++ & + & ++ & + \\
\hline Nitzschia sigma (Kützing) W. Smith (ab) & + & + & + & ++ & + & ++ & ++ & + & ++ & ++ & +++ & ++ \\
\hline Nitzschia vermicularis (Kütz.) Hantzsch in Rabenh & + & & & & & & + & & & & & \\
\hline Odontella aurita (Lyngbye) C.A. Agardh (ab) & & + & & + & + & + & + & + & + & & & \\
\hline Odontella obtusa (Kützing) Ralfs (ab) & + & ++ & + & + & + & + & + & ++ & + & + & ++ & ++ \\
\hline Odontella sinensis (Greville) Grunow (WoRMS) & & & & & & & & & + & & & \\
\hline Paralia sulcata (Ehrenberg) Cleve (ab & & & & + & & & & & & & & \\
\hline Plagiotropis lepidoptera (Gregory) Kuntze (ab) & & + & & + & + & + & + & + & ++ & + & + & \\
\hline Pleurosigma angulatum W. Smith (ab) & & + & & & + & + & + & + & + & + & + & \\
\hline $\begin{array}{l}\text { Proboscia alata var.gracillima* (Brightwell) Sündstrom } \\
\quad(\mathrm{ab})\end{array}$ & ++ & +++ & ++ & +++ & +++ & ++ & +++ & +++ & +++ & ++ & ++ & +++ \\
\hline Proboscia alata form indica* Brightwell) Sündstrom (ab) & & + & + & ++ & & & & & + & & & \\
\hline Pseudosolenia bergoni H. Péragallo (ab) & & & & & & & & & + & & & \\
\hline Pseudosolenia calcar avis (Schultze) Sundström (ab) & ++ & +++ & ++ & +++ & +++ & ++ & ++ & +++ & +++ & +++ & +++ & ++ \\
\hline Rhizosolenia fragilissima Bergon & & + & & + & + & + & + & & & & + & \\
\hline Rhizosolenia imbricata (Cleve) Schröder WoRMS) & & ++++ & + & + & + & + & + & + & +++ & & ++ & \\
\hline Rhizosolenia stoterfothii H. Peragallo (ab) & & + & & + & + & + & + & & & + & + & \\
\hline Rhizosolenia styliformis Brightwell (ab) & + & + & & + & + & & & & + & + & + & + \\
\hline Skeletonema costatum* (Greville) Cleve (ab) & + & + & + & + & & + & & & + & & & + \\
\hline $\begin{array}{l}\text { Stephanopyxis turis (Greville \& Arnott in Gregory) Ralfs in } \\
\text { Pritchard }\end{array}$ & & + & & & & & & + & - & + & + & \\
\hline Striatella unipunctata (Lyngbye) C. Agardh (ab) & & & & + & & & & & + & & & \\
\hline Surirella minuta Brébisson (WoRMS) & ++ & + & ++ & + & + & + & + & + & + & + & + & + \\
\hline Surirella robusta Ehrenberg (ab) & + & & + & & & & & & & & & + \\
\hline Synedra acus Kütz. & + & + & + & + & & + & + & & + & & & + \\
\hline Synedra crystalline (C.Agardh) Kützing (WoRMS) & & + & & & & & & & & & & \\
\hline Synedra ulna (Nitzsch) Ehrenberg (ab) & ++ & ++ & + & ++ & ++ & ++ & ++ & ++ & ++ & ++ & +++ & ++ \\
\hline Synedra undulata (J.W.Bailey) Gregory (ab) & + & + & + & & + & + & + & + & + & + & + & + \\
\hline
\end{tabular}


Table 2 (continued)

\begin{tabular}{|c|c|c|c|c|c|c|c|c|c|c|c|c|}
\hline Algal groups & 1 & 2 & 3 & 4 & 5 & 6 & 7 & 8 & 9 & 10 & 11 & 12 \\
\hline $\begin{array}{l}\text { Thalassionema nitzschioides* (Grunow) Mereschkowsky } \\
\text { (ab) }\end{array}$ & + & + & + & + & + & & & + & + & & + & + \\
\hline Thalassiosira sp. & + & & & & + & ++ & ++ & & & & & \\
\hline Thalassiothrix frauenfeldii (Grunow) Grunow (WoRMS) & & ++ & & ++ & + & + & & + & ++ & + & + & \\
\hline Thalassiothrix longissima Cleve \& Grunow (ab) & ++ & ++ & ++ & +++ & ++ & ++ & ++ & ++ & +++ & +++ & +++ & +++ \\
\hline Trachyneis aspera (Ehrenberg; Ehrenberg) Cleve & & + & & + & ++ & + & + & + & & + & ++ & \\
\hline \multicolumn{13}{|l|}{ Cyanophytes } \\
\hline Anabaena sp. & & + & & & & & & & & & & \\
\hline Chroococcus minutus (Kütz.) Nägeli & + & & ++ & & ++ & & + & + & + & & + & + \\
\hline Chroococcus turigidus (Kützing) Nägeli (ab) & & + & + & & + & & & & + & & & + \\
\hline Coelosphaerium sp. & + & & + & + & + & + & & & + & & + & + \\
\hline $\begin{array}{l}\text { Lyngbya major Pseudoanabaena Meneghini ex } \\
\text { Gomont (ab) }\end{array}$ & & & & & & & & + & & ++ & + & \\
\hline Lyngbya majuscula Harvey ex Gomont (WoRMS) & & + & & & + & & + & & & ++ & + & \\
\hline Microcystis sp & & + & + & + & + & & & & + & & + & + \\
\hline Trichodesmium erythraeum *(Ehrenberg) Geitler (ab) & + & + & + & + & +++ & + & +++ & ++ & ++ & +++ & +++ & +++ \\
\hline Pseudanabaena limnetica* (Lemmermann) Komárek (ab) & ++ & ++ & ++ & + & +++ & ++ & +++ & ++ & ++ & +++ & ++ & ++ \\
\hline Oscillatoria simplicissima* Gomont (WoRMS) & & + & + & + & + & + & + & ++ & + & +++ & + & ++ \\
\hline Oscillatoria sp. & + & +++ & ++ & + & ++ & + & ++ & + & ++ & ++ & ++ & ++ \\
\hline Oscillatoria tenuis* C. Agardh (WoRMS) & & + & + & & + & & + & + & + & ++ & + & + \\
\hline Phormidium sp. & ++ & ++ & ++ & + & ++ & ++ & ++ & ++ & ++ & +++ & ++ & ++ \\
\hline Planktothrix formosa* & + & + & + & + & + & + & + & + & + & ++ & + & ++ \\
\hline Spirulina major Kützing ex Gomont (WoRMS) & ++ & & & & & & & & & & & + \\
\hline Spirulina sp. & & & + & & & & & & & + & & \\
\hline \multicolumn{13}{|l|}{ Dinoflagellates } \\
\hline Ceratium breve (Ostenfeld \& Schmidt) Schroder (ab) & + & & + & & & & & & & + & + & + \\
\hline Ceratium egyptiacum Halim (ab) & & & & & & & & & + & & & \\
\hline Ceratium extensum (Gourret) Cleve-Euler (ab) & + & & & & & & + & & & & & + \\
\hline $\begin{array}{l}\text { Ceratium furca* (Ehrenberg) Claparède \& Lachmann } \\
\text { (WoRMS) }\end{array}$ & + & + & + & + & & & & + & + & & & + \\
\hline Ceratium fusus* (Ehrenberg) Dujardin (ab) & + & & + & & + & & & & + & & & + \\
\hline Ceratium karastenii Pavillard (WoRMS) & & & & & & & & & + & & & \\
\hline Ceratium macroceros (Kofoid) Peters (ab) & + & + & + & & + & & & + & + & & + & + \\
\hline Ceratium massiliense (Gourret) E.G.Jørgensen (ab) & + & + & + & + & & + & + & + & ++ & & + & + \\
\hline Ceratium trichoceros (Ehrenberg) Kofoid (WoRMS) & + & + & + & ++ & + & + & + & + & ++ & +++ & +++ & + \\
\hline Ceratium tripos* (O.F.Müller) Nitzsch (WoRMS) & + & + & + & + & + & + & + & + & + & ++ & ++ & + \\
\hline Dinophysis caudata* Saville-Kent (ab) & & + & & & & & & & + & + & + & \\
\hline Dinophysis sp. & & & & + & & & & & & & & \\
\hline Diplopsalis lenticula & & & & & & + & & & + & & + & \\
\hline Exuviaella compressa (Bailey) Knudsen \& in Ostenfeld (ab) & & + & & + & + & ++ & + & + & + & ++ & ++ & \\
\hline Goniaulax sp. & & & & & + & & + & & & + & & \\
\hline Gymnodinium sp. & & & & + & & & & & + & & & \\
\hline Oxytoxum gracile J.Schiller & & & & & & + & & & & & + & \\
\hline Phalacroma sp. & & & & + & & & & & & & & \\
\hline Podolampas palmipes Stein & & + & & & & + & & + & & & & \\
\hline Prorocentrum compressum (J.W. Bailey) Abé ex Dodge & & & & & & & & & + & & & \\
\hline
\end{tabular}


Table 2 (continued)

\begin{tabular}{|c|c|c|c|c|c|c|c|c|c|c|c|c|}
\hline Algal groups & 1 & 2 & 3 & 4 & 5 & 6 & 7 & 8 & 9 & 10 & 11 & 12 \\
\hline Prorocentrum micans* Ehrenberg (ab) & & + & & + & & & & & & & & \\
\hline Prorocentrum minimum $*$ (Pavillard) Schiller & & + & & & & & + & & + & + & & \\
\hline Protoperidinium minutum (Kofoid) Loeblich III & & + & & + & + & + & + & + & + & + & + & \\
\hline Protoperidinium cerasus (Paulsen) Balech (ab) & + & + & + & + & + & + & + & + & + & + & + & + \\
\hline Protoperidinium depressum (Bailey) Balech (CaRMS) & & + & & & & + & & + & & + & & \\
\hline Protoperidinium divergens (Ehrenberg) Balech (CaRMS) & & & & & & & & + & & & & \\
\hline Protoperidinium ovatum Pouchet (CaRMS) & & & & + & & + & & & & & & \\
\hline Pyrophacus horologicum Stein (ab) & & + & & & & & & & + & & & \\
\hline \multicolumn{13}{|l|}{ Chlorophytes } \\
\hline Dictyosphaerium sp. & & + & & & & & & & & & + & \\
\hline Pediastrum clathratum. (Schröder) Lemmermann (ab) & & & & & & & & & & & + & \\
\hline Pleurotaenium trabecula Nägeli (ab) & +++ & + & +++ & +++ & ++++ & +++ & ++++ & +++ & +++ & +++ & ++ & +++ \\
\hline Treubaria crassipina G. M. Smith (WoRMS) & & & & & & & + & + & & ++ & & \\
\hline
\end{tabular}

Note: 0-50 rare,$+>50-100$ frequent,$++>100-200$ common,$+++>200$ abundant ++++

The species marked with astrics are potential harmful

Table 6 The correlations between total phytoplankton counts, phytoplankton classes, dominant species and the physico-chemical parameters during 2012-2013

\begin{tabular}{|c|c|c|c|c|c|c|}
\hline & Temp & $\mathrm{pH}$ & DO & $\mathrm{PO}_{4}$ & $\mathrm{NO}_{3}$ & $\mathrm{NH}_{4}$ \\
\hline & ${ }^{\circ} \mathrm{C}$ & - & $\mathrm{mgO}_{2} / 1$ & $\mu \mathrm{M}$ & & \\
\hline Total phytoplankton & -0.20 & -0.63 & 0.51 & 0.44 & 0.66 & -0.47 \\
\hline Diatoms & -0.51 & -0.69 & 0.48 & 0.69 & 0.63 & -0.46 \\
\hline Dinoflagellates & 0.01 & -0.22 & 0.52 & 0.33 & 0.34 & -0.09 \\
\hline Cyanophytes & 0.27 & -0.18 & 0.19 & 0.14 & 0.27 & -0.18 \\
\hline Chlorophytes & 0.38 & -0.08 & -0.02 & 0.02 & 0.17 & -0.22 \\
\hline Chaetoceros lorenzianus & -0.08 & -0.35 & 0.07 & 0.42 & 0.50 & -0.51 \\
\hline Gyrosigma attenuatum & 0.09 & -0.20 & 0.14 & 0.39 & 0.49 & -0.27 \\
\hline Pseudosolenia calcar-avis & 0.10 & -0.24 & -0.03 & 0.28 & 0.40 & -0.49 \\
\hline Pleurotaenium trabecula & 0.38 & -0.02 & -0.05 & -0.03 & 0.11 & -0.16 \\
\hline Proboscia alata var.gracillima & 0.33 & 0.27 & 0.07 & -0.10 & -0.15 & 0.23 \\
\hline Pseudo-Nitzschia pungens & -0.45 & -0.43 & 0.31 & 0.63 & 0.52 & -0.32 \\
\hline Trichodesmium erythraeum & 0.29 & -0.15 & 0.17 & 0.14 & 0.25 & -0.17 \\
\hline Pseudanabaena limnetica & 0.50 & 0.10 & -0.01 & -0.04 & 0.10 & -0.03 \\
\hline
\end{tabular}

Note: Bold correlations are significant at $p<0.05$ and $n=47$ ) 
In the Correlation matrices and multiple regressions under Statistical Analysis section the corrected paragraph is shown below.

The statistical analysis of the data indicated that the phytoplankton abundance was positively correlated with nitrate $(\mathrm{r}=0.66)$ and dissolved oxygen $(\mathrm{r}=0.51)$ but inversely correlated with $\mathrm{pH}$ values $(\mathrm{r}=-0.63)$ and with ammonia $(r=-0.47)$, whereas the groups and dominant species showed varied correlations with physicochemical characteristics as shown in Table 6. The multiple regression analysis indicated that the dissolved nitrate and $\mathrm{pH}$ values were the most effective factors that controlled the seasonal fluctuations of phytoplankton in the eastern coast of Suez Gulf during 2012-2013. The regression model was phytoplankton counts $=1379.2341+0.662 \mathrm{NO}_{3}-0.33$ $\mathrm{pH}(\mathrm{MR}=0.662, \mathrm{~N}=47, p<0.1278)$. The similarity index revealed four clusters (Fig. 3).

In the Discussion section the corrected paragraphs are shown below.

In general, the high nitrate concentrations enhance the phytoplankton growth during the study period. This was confirmed by the positive correlation between NO3 and the total counts of phytoplankton $(r=0.66)$ and the regression analysis (phytoplankton counts $=1379.2341+0.662$ $\left.\mathrm{NO}_{3}-0.33 \mathrm{pH}\right)$. However, natural phytoplankton communities typically prefer to take up nitrogen in the reduced form of ammonium rather than the oxidized forms nitrite and nitrate. In the present study there was a negative correlation between total phytoplankton abundance and ammonium $(r=-0.47)$ and there was a negative correlation between diatoms and ammonium $(\mathbf{r}=-\mathbf{0 . 4 6})$. This may be due to that various phytoplankton groups and taxa exhibit differential abilities to take up and assimilate dissolved organic nitrogen vs. dissolved inorganic nitrogen (Twomey et al. 2005). Due to the low values of dissolved phosphate $(0.025-0.3 \mu \mathrm{M})$, nitrate $(0.18-1.26 \mu \mathrm{M})$, and relatively high concentration of ammonium (0.81-5.36 $\mu \mathrm{M})$ during 2012-2013, the eastern coast of Suez Gulf is still healthy, relatively unpolluted, and oligotrophic to mesotrophic area. This is established with the data reported by Fahmy (2003) who concluded that nitrogen, phosphorus, and reactive silicate concentrations were generally low and allowed classifying the Egyptian Red Sea coastal water as oligotrophic to mesotrophic. This is in addition to the relatively low total abundance of phytoplankton (average of 2989 unit/L), compared with the data reported in its western coast in 1995 (average of 5862 unit/L) by Nassar (2000) and in 2006 (average 15,591 unit/L) by Nassar (2007a), as well as the data reported in 2002 by Shams El-Din et al.(2005) along the both sides of Suez Gulf (average of 6284 unit/L). However, Ghobrani et al. (2014) mentioned that oligotrophic waters are characterized by high clarity and little counts of algae.

However, the relative high abundance of phytoplankton in this study was found at St. 9 followed by St. 10 with total counts of 4169 and 3840 unit/L, respectively. This may be due to their subject to fractions of petroleum hydrocarbons and sewage discharge, which could promote the phytoplankton growth as reported by Nayar et al. 2005 and Nassar et al. 2014. On the other hand, the lowest occurrence of phytoplankton was recorded at St. 1 and St. 3, with similar total counts of 2218 and 2251 unit/L, respectively. This may be due to the effect of thermal waters discharged from the cooling systems of the Electrical Power Station of Ayon Mousa near St. 1 , as well as the high tourist and human activities at the beach of Ras Sedr near St. 3.

As all marine coastal areas, diatoms were the dominant group forming high percentage $(67.48 \%)$ and prevailed during the four seasons (53.03-82\%) and at all stations (57-80\%). Whereas, the cyanophytes were the second dominant group, indicating the presence of freshwater discharge in the study area. On the other hand, the contribution of three groups Cyanophyceae, Dinogflagellates, and Chlorophyceae increased during summer at high temperature $\left(28.1-31.5^{\circ} \mathrm{C}\right)$. Eker and Kideyș (2000) suggest that there is a positive relationship between dinoflagellates and water temperature; thus, dinoflagellates may be better adapted to the high temperatures. Most dinoflagellates are found in temperate waters, are most prevalent in summer months (Taylor 1987), and dominate the phytoplankton in warm seasons (Tait 1981). In this connection, Schabhüttl et al. (2012) reported that green algae and diatoms showed a trend to perform better at lower temperatures, while Cyanobacteria showed stronger responses with increasing temperatures in mixed communities. In the present study, temperature was negatively correlated with diatoms $(r=-0.51)$, whereas it was not a 


\section{limiting factor for dinoflagellates, cyanophytes and chlorophytes.}

The similarity index based on spatial and temporal fluctuations of phytoplankton counts revealed four clusters: cluster 1 (St. 1, 3, and 12), cluster 2 (St. 10), cluster 3 (St. 4, 6, and 9), cluster 4 (St. 2, 8, 5, 7, and 11). The lowest similarity level was $41.11 \%$ between St. 1 and St. 10, whereas the highest level was $76.91 \%$ between St. 3 and St. 12. However, cluster 2 , which includes only one station, reflects the unique ecological conditions at this station (oil effluents from Petropil Company). In contrast, the other clusters indicated that the included stations in each cluster have more or less similar ecological conditions, depending on the degree of similarity.
In the Conclusion section the corrected paragraph is shown below.

The study area is considered as oligotrophic to mesotrophic and healthy, despite land-base, human, and tourism activities, since the total counts of phytoplankton was low accompanied with generally low nutrient concentrations and high values of diversity. But due to the appearance of potentially harmful algae species even in low counts, make the region of the eastern coast susceptible to drastic effects at flourishing of these species during favorable conditions. Thus, monitoring continuously of this area is imperative, to follow probable bloom of these species, to predict negative effects resulting from increasing landbased activities in order to protect the eastern coast of Suez Gulf from any undesirable change there. 